\title{
Waterbird habitat loss fringing the Yellow and Bohai seas along the East Asian-Australasian migratory flyway
}

\author{
Houlang Duan ${ }^{1}$, Xiubo $\mathrm{Yu}^{2}$, Shaoxia Xia ${ }^{3}$, and Guangshuai Zhang ${ }^{4}$ \\ ${ }^{1}$ Institute of Geographic Sciences and Natural Resources Research, CAS \\ ${ }^{2}$ Institute of Geographic Sciences and Natural Resources Research Chinese Academy of \\ Sciences \\ ${ }^{3}$ Institute of Geographic Sciences and Natural Resources Research CAS \\ ${ }^{4}$ National Marine Environmental Monitoring Center, Dalian 116023, China
}

February 2, 2021

\begin{abstract}
Natural wetland along the coasts of Yellow and Bohai seas provided key stopover sites for migratory waterbirds. However, these wetlands are facing land loss. Understanding how natural wetlands loss influence habitat is an important step for habitat management. Using species distribution model to report changes in area of suitable habitat, and the effects of natural wetland loss on habitat for 80 waterbird species attributed to four functional categories (shorebird, duck, heron, gull), between 2000 and 2015 in the Yellow and Bohai seas. Of $1794.8 \mathrm{~km} 2$ of coastal wetland lost to development between 2000 and 2015 , most represented tidal flats converted into aquaculture and salt pan habitat, or for construction. Consequently, habitat for 73 of these 80 species has decreased in area over this time period. Generally, the proportional decline in habitat suitable for species of duck was less than it was shorebirds, herons and gulls. The proportional loss of tidal flat habitat that formerly represented suitable habitat for shorebirds, herons and gulls was also significantly higher than it was for ducks. Because more species of duck exploit aquaculture and salt pan habitat converted from tidal flats than do shorebird, heron and gull species, such conversion of tidal flats pose a greater threat to shorebirds, herons and gulls than they do to ducks. Preventing further reclamation of tidal flats and managing artificial wetlands are priorities for waterbirds conservation, especially for the species ducks.
\end{abstract}

\section{Hosted file}

Manuscript.pdf available at https://authorea.com/users/393237/articles/506903-waterbirdhabitat-loss-fringing-the-yellow-and-bohai-seas-along-the-east-asian-australasianmigratory-flyway

\section{Hosted file}

Covering_letter.pdf available at https://authorea.com/users/393237/articles/506903-waterbirdhabitat-loss-fringing-the-yellow-and-bohai-seas-along-the-east-asian-australasianmigratory-flyway

\section{Hosted file}

Highlights.pdf available at https://authorea.com/users/393237/articles/506903-waterbirdhabitat-loss-fringing-the-yellow-and-bohai-seas-along-the-east-asian-australasianmigratory-flyway

\section{Hosted file}


Title page.pdf available at https://authorea.com/users/393237/articles/506903-waterbirdhabitat-loss-fringing-the-yellow-and-bohai-seas-along-the-east-asian-australasianmigratory-flyway 